\title{
BANK SPECIFIC AND MACROECONOMIC DETERMINANTS: EMPIRICAL EVIDENCE FROM REPUBLIC OF NORTH MACEDONIA
}

\author{
Kalterina Abazi Jusufi ${ }^{1}$ \\ Adriatik Abazi ${ }^{2}$ \\ ${ }^{1}$ University "St. Cyril and Methodius"- Skopje, Republic of North Macedonia, Economic Faculty, \\ E-mail: kalterinaabazi@ hotmail.com ${ }^{1}$ \\ 2" State University of Tetova", Republic of North Macedonia, Economic Faculty, E-mail: \\ adriatik.abazi@hotmail.com2
}

\begin{abstract}
This study examined the impact of bad loans on banks profitability, because banks are the most important participants in the financial system, but also the most significant and largest financial institutions around the world, measured through their share in the total financial sector assets and for this, the purpose of this paper is to study impact of bank-specific and macroeconomic determinants on bank profitability in Republic of North Macedonia.
\end{abstract}

A strong financial system is very important for a country to flourish. The economic progress of a nation and development of banking is invariably interrelated. The banking sector is important financial service sector because channelizing funds for productive purpose.

The objective of this study is to examine the impact of bank-specific and major macroeconomic factors on the profitability of banking sector in Republic of North Macedonia by using the data over the time period 1994-2016. This study used unbalanced time series data with OLS methods, which were collected from World Bank and National bank in Republic of North Macedonia. This paper employs the Ordinary Least Square method to investigate also the effect of loans, economic growth and other determinants showed with the level of the profitability in Republic of North Macedonia, because the purpose of this study is to find out the causes of loans in Republic of North Macedonia. However, some of these loans usually fall into non- performing loans and adversely affect the performance of bank profitability.

The main goal of this paper is the impact of internal and external factors which can be classified also into bank-specific and macroeconomic factors on bank profitability in Republic of North Macedonia as one of the countries that is in transition.

The paper sets out to determine the main factors and their level of impact on profitability of banks in the Republic of North Macedonia and showed that the loans have negative impact on the bank profitability in the Republic of North Macedonia, but also results showed the individual effects on profitability where in some variables coefficients are statistically significant. Moreover, results showed a positive but insignificant impact of the macroeconomic determinants such as growth.

Keywords: financial system, banking profitability, non-performing loans, OLS, Republic of North Macedonia, Social Sciences 


\section{Introduction}

A bank is a financial institution that accepts deposits from the public and creates credit. Lending activities can be performed either directly or indirectly through capital markets. Banks may also provide financial services, such as wealth management, currency exchange, and safe deposit boxes.

Banks play a vital role in economic growth, namely by diversifying the risk to their activity. Interest rate risk is one of the most important financial risks of each bank which the banks face. Each risk is in itself a direct or indirect negative impact on the profit, activity, or realization of the ultimate goal of the banks. The risk of a change in interest rates in the portfolios of banking activities is a risk of loss arising from unfavorable changes in interest rates, as seen by the bank.

The main goal of this paper is the impact of internal and external factors which can be classified also into bankspecific and macroeconomic factors on bank profitability in Republic of North Macedonia as one of the countries that is in transition. The main research question is: Is there a significant link between banking and macroeconomic factors, such as Non-performing loans and GDP growth on bank profitability in Republic of North Macedonia. What effect do macroeconomic factors have in the bank profitability in the banking sector in Republic of North Macedonia?

The methodology of this research is based on the unbalanced time series data and OLS - Ordinary Least Square method. The data used are annual from 1994 to 2016 and the research is structured in this way. The section 2 is talking about the literature review and the used methodology, also in this section will describes the performance indicators being studied in the banking system in Republic of North Macedonia. Section 3 corresponds to the description of the data obtained in the study and will show the main results identified through the linear regression model. In section 4 will be the conclusions and recommendations and in the end of this research are references.

\section{Theoretical Literature Review and Methodology}

The performance of banking sector is also activity applied to a part of performance of an action in a time period, often with connection to previous expenditure efficiency or management responsibility (Abugamea, 2018, p. 117). But banking sectors play a key role in the development of an economy. The development role undertaken by banking sector determines the step for development of economy. Hence the stability of banking sector is a key for the development of an economy.

Therefore, commercial banks are one of the banking sectors which are the main source of funding to business activities as well as other projects throughout the country. They play a key role in the economy by mobilizing deposits from surplus units to deficit units in the form of loan and advances (Bhattarai, 2015).

As literatures show, there have been an increased number of significant bank problems both at matured and emerging economies (Joseph, Edson, Manuere, Clifford, Michael, 2012). Banking sectors can perform worst as a result of inefficient management, low capital adequacy and poor assets quality. Non-performing assets is also the single largest cause of irritation of the banking sectors (Sontakke and Tiwari, 2013).

This research is an explanatory research design that identifies the cause and relationships effect between the NPLs and other banking and macroeconomic determinants. A lot of studies were conducted on the difficulty of nonperforming loans for banking sectors.

Similar studies are made for loans and bank profitability, because the main effect of bad loans is the ability to deter the bank to grow financially. This is because bad loans drag banks into liquidity problems and make them unable to extend funds to other potentially viable businesses. (Karim, 2010) also maintained that the banks cannot take up some procreative investment opportunities because of locked up capital due to bad loans and makes banks experience shortfalls in revenue generation. (Karim, Chan and Hassan, 2010, p. 118-132).

To this end, the main objective of this study was to examine the bank specific and macroeconomic determinants of NPLs of banks in Republic of North Macedonia. This initiates the bank management and executives with applied knowledge on the management of identified variables and provides them with understanding of activities that will enhance their loan quality and play a vital role in filling gap in understanding the determinants of banking sector in Republic of North Macedonia.

\section{Overview of banking system in Republic of North Macedonia in 2017-2019}

According on the report of National Bank of the Republic of North Macedonia (2017-2019), the activities of the banks in 2017 had different tendencies in the first and in the second half of the year. In the first half of 2017 the activities of the banks were under the influence of the reduced economic activity and still were present risks from the domestic political events and the global environment. The total assets of the banks in this period featured 
modest growth which was primarily due to the decline in the deposit potential of the banks in the first quarter of 2017 and due to the minimal growth in the second quarter of the year. The gradual stabilizing of the situation and the ascertainments of the economic entities in the second half of 2017 has relevant impact on the positive tendencies on the foreign currency market and on the upward tendency of the deposit base of the banks, mainly from the households.

In conditions of stable expectations of domestic economic agents, with healthy economic fundamentals and absence of imbalances in the economy, the overall activities of the banking system in 2018 grew rapidly. The growth of the bank's assets mostly stems from the rapid growth of deposits and reflects the rapid growth of credit activity by non-financial entities and liquid funds. The increase in lending is largely due to the household denar loans.

Credit risk realization, measured through the trend of non-performing loans, declined in 2018, as non-performing loans declined by $12 \%$ (unlike 2017, when these loans increased by $2 \%$ ). Participation of non-performing loans in total for nonfinancial entities also improved and decreased to the level of 5.2\% (6.3\% in 31.12.2017) and this according to report of NBRNM, 2018. (http://www.nbrm.mk/banking_system_reports.nspx.)

On the other hand, credit risk realization, reflected by the growth of non-performing loans (1.3\%), slowed down in the first quarter of 2019, compared to the last quarter of $2018(6.8 \%)$. The bulk (almost 80\%) of the quarterly growth of non-performing loans is attributable to the increase in these loans to nonfinancial companies, which was spread over several sectors (construction, trade, vocational, scientific and technical activities and certain industries). However, non-performing loans of the households also increased in the first four quarters of 2019 (by $1.4 \%$ ), which is a consequence of the growth of non-performing consumer and non-performing loans for purchase and renovation of business and residential premises. Participation of non-performing loans in total to the nonfinancial entities remained at the same level (of 5.2\%) as in 31.12.2018, between this unchanged ratio of households $(2.3 \%)$ and minimum growth of 0.1 percentage points, to non-financial companies $(8.1 \%$ in March $31,2009)$. High coverage of non-performing loans with impairment was also maintained in the first quarter of $2019(76.5 \%)$, which at satisfactory volume and quality of its own funds limits the negative effects on the solvency of the banks, due to the possible non-payment of these loans.

\section{Data Specification}

The research subject of this paper are NPLs and bank profitability in the banking systems of the Republic of North Macedonia, their dynamics, sectoral structure, and the basic determinants of growth, due to the fact that the bad loan portfolio is one of the most important factors of instability of banks and the banking system as a whole and as such, it produces negative effects on the overall economic activity of the country.

Most of the literatures explore the factors that determine non-performing loans, make use of the linear regression model, while implementing in parallel macroeconomic and bank-specific determinants. Accordingly, this chapter discussed the research procedure that is used to carry out this study. In case, it starts by discussing research design followed by the nature and instruments of data collection and sampling design. The subsequent section presents and discusses method of data process and analysis.

Primary data in this study are derived from secondary sources, mainly identified from annual reports and statistics published by the National Bank of the Republic of North Macedonia (2017), World Bank (2019), FRED Economic data ST. Louis FRED (2019), different data and information reports. The methodology of research is based on the time series method by the Ordinary Least Square. Identified data are processed by the statistical program Eviews 9.0. Initially, the relevant tests have been developed for evaluation of variables and construction of the final model of linear equation. The study used secondary sources that span from 1994 to 2016. Annual time series data for each of the variables; return on equity (ROE), Non-Performing Loan (NPL), GDP growth (GDP) and Liquid liabilities to GDP (LIQ).

This research used descriptive analysis and multiple regression analysis methods to analyze data. To ensure that the sample matched with multiple methods of regression analysis, data was tested for normality, multi co-linearity and heteroskedasticity. No significant violations were found. A regression model is estimated to examine the relationship between NPL and ROE. The model is expressed as:

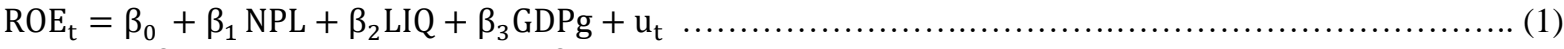

Whereas: $\beta_{0}=$ Constant parameter; $\beta_{1-3}=$ Coefficients of independent variables; $u_{t}=$ Represents the unexplained residual and $\mathrm{t}=$ time. Where, ROE: return on equity (dependent variable), NPL: Non-Performing Loans, LIQ: Liquid liabilities to GDP and GDP growth: GDP growth. According to these data, hypotheses are:

I. Hypothesis The macroeconomic variables will affect the performance of banks in Republic of North Macedonia. 
ISSN 2661-2666 (Online) International Scientific Journal Monte (ISJM) DOI: 10.33807/monte.202004663 Volume 2. No. 1 (2019): April

II. Hypothesis The macroeconomic variables will not affect the performance of banks in Republic of North Macedonia, respectively in the normal period.

\section{Results}

Times series data is used in this study from 1994-2016, all data are obtained from NBRNM (2018), World Bank, IMF (2018) and FRED Economic data | ST. Louis FED. Identified data were processed by the statistical program Eviews 9.0. Table 1 below also shows the descriptive statistics of all data used in the study.

\begin{tabular}{lcccc}
\hline \multicolumn{6}{|l}{ Table 1. Descriptive statistics of variables impacting ROE } \\
& ROE & NPL & $\begin{array}{l}\text { LIQ. LIABIL. TO } \\
\text { GDP }\end{array}$ & GDP GROWTH \\
\hline Mean & 7.424286 & 17.66263 & 34.43706 & 2.390509 \\
Median & 7.860000 & 10.93000 & 33.20130 & 2.924381 \\
Maximum & 16.52000 & 41.30000 & 54.42080 & 6.473487 \\
Minimum & -5.750000 & 6.280000 & 11.11710 & -3.067246 \\
Std. Dev. & 4.704701 & 12.43570 & 16.11064 & 2.490889 \\
& & & & 23 \\
Observations & 23 & 23 & 23 & \\
\hline
\end{tabular}

Source: Author's calculations

This study was used to find the impact of independent variable on bank profitability, by using following variables NPL, Liquid liabilities to GDP and GDP growth, with 23 observations. As it can be seen from Table 1, the results show that NPL had an average of $17 \%$ and Std. Dev. 12.43570, the maximum and minimum values are 41.30000 and 6.280000, respectively. Liquid liabilities to GDP had an average of 34\% and Std. Dev. 16.11064, the maximum and minimum values are 54.42080 and 11.11710 respectively, GDP growth had an average of 2\% and Std. Dev. 2.490889, the maximum and minimum values were 6.473487 and -3.067246 .

\section{Correlation of variables impacting ROE}

Relevant tests identified: the test of autocorrelation and multi co-linearity test. Multi co-linearity test serves to evaluate the linear relationship between the variables. The results are shown in Table 2, which suggests that multi co-linearity does not exist.

\begin{tabular}{llccc} 
Table 2. Correlation & $\Delta$ ROE & $\Delta$ NPL & $\Delta$ LIQ & GDP growth \\
\hline$\Delta$ ROE & 1.000000 & -0.580376 & -0.357827 & 0.338675 \\
$\Delta$ NPL & -0.580376 & 1.000000 & -0.265152 & -0.028049 \\
$\Delta$ LIQ & -0.357827 & -0.265152 & 1.000000 & -0.130076 \\
GDP G & 0.338675 & -0.028049 & -0.130076 & 1.000000
\end{tabular}

Source: Author's calculations

This model was tested also for autocorrelations with $\mathrm{DW}=2.62$. The results suggest that positive autocorrelation is not significant and to continue with data analysis. 
ISSN 2661-2666 (Online) International Scientific Journal Monte (ISJM) DOI: 10.33807/monte.202004663 Volume 2. No. 1 (2019): April

\section{Results of regression analysis and descriptive}

On the basis of the results from the testing it is possible to make transformations of series and their modeling, with Unit Root test (Bucevska, 2016). The series of ROE, non-performing loans and liquid liabilities to GDP are non-stationary series for our model, so the final econometric model for bank profitability and non-performing loans is presented in this form:

$\Delta \mathrm{ROE}=0.020487 \mathrm{C}-0.602384 \Delta \mathrm{NPL}-0.934559 \Delta \mathrm{LIQ}+0.458974 \mathrm{GDPgrowth}$

The estimation coefficient of the non-performing loan ratio was negative and statistically significant, which indicates that the higher the level of non-performing loans is the lower is the level of bank profitability (ROE). The estimated coefficient of Liquid liabilities to GDP was negative and statistically significant and the coefficient of GDP was positive and statistically insignificant.

The following will appear statistical tables of results of all variables (dependent and independent).

Table 3. The results of the model

\begin{tabular}{||l|l||l||}
\hline $\begin{array}{l}\text { Method: OLS } \\
\text { Independent } \\
\text { Variables }\end{array}$ & Coefficient & Prob. \\
\hline \hline C & 0.020487 & 0.9873 \\
\hline \hline$\Delta$ NPL & -0.602384 & 0.0005 \\
\hline \hline$\Delta$ LIQ & -0.934559 & 0.0059 \\
\hline \hline GDP growth & 0.458974 & 0.1210 \\
\hline
\end{tabular}

\begin{tabular}{|l|l|}
\hline R-squared & $68 \%$ \\
\hline Adjusted R-squared & $61 \%$ \\
\hline Prob (F-statistic) & $0.000903 ;$ \\
DW & 2.62 \\
\hline
\end{tabular}

Source: Author's calculations

\section{Normality test for the model and heteroskedasticity test}

The model was tested for normality, when the residuals are normally distributed and the probability of Jarque Bera is $62 \%$, which mean that the variables are normally distributed.

The model was also tested for Heteroskedasticity with Breusch-Pagan-Godfrey test and this is showed in Table 4.

Table 4. Heteroskedasticity Test

Heteroskedasticity Test: Breusch-Pagan-Godfrey

\begin{tabular}{llll}
\hline \hline F-statistic & 0.289935 & Prob. F(3,14) & 0.8319 \\
Obs*R-squared & 1.052905 & Prob. Chi-Square(3) & 0.7885 \\
Scaled explained SS & 0.345035 & Prob. Chi-Square(3) & 0.9513 \\
\hline \hline
\end{tabular}

Source: Author's calculations

Table 4, shows that we do not reject the zero hypothesis which implies that the remains are homoscedastic

\section{Conclusion and Recommendations}

In this study we used unbalanced time series data from 1994 to 2016 and OLS method with macroeconomic and banking sector variables, because for analysis's taken banking sector in Republic of North Macedonia.

The results are compatible with the prepositions for all variables and with the literature we have read. The p- value for two independent variables is less than 0.05 which indicates a significant relationship between the dependent and independent variables. The macroeconomic variable is insignificant because the $\mathrm{p}$ - value is greater than 0.05 . Also, in this study, we found that an increase in non-performing loans affects a decrease in bank profitability (ROE). These results support the theory, which argues that increased credit risk exposure, measured by nonperforming loans, usually is associated with an increase in operating costs and leads to reduced profitability. 
ISSN 2661-2666 (Online) International Scientific Journal Monte (ISJM) DOI: 10.33807/monte.202004663 Volume 2. No. 1 (2019): April

In many studies, in other countries we read that a lot of factors influencing different types of non-performing loans, but in this model the independent variable explains about 68\% of the model in the period 1994-2016, which would say that the model provides $68 \%$ base for the forecast. 
ISSN 2661-2666 (Online) International Scientific Journal Monte (ISJM) DOI: 10.33807/monte.202004663 Volume 2. No. 1 (2019): April

\section{References}

Abugamea, G. (30 May 2018). Determinants of Banking Sector Profitability: Empirical Evidence from Palestine. Munich Personal RePEc Archive. No. 89772. 1-17. Retrieved from: https://mpra.ub.unimuenchen.de/89772/.

Bucevska, V. (2016). (Ed(s)). Econometric with Eviews. (Second edition, ed). Skopje: University "St. Cyril and Methodius", Faculty of Economic.

Bhattarai, R.Y. (2015). Determinants of Lending Interest Rates of Nepalese Commercial Banks, Economic Journal of Development Issues Vol. 19 \& 20 No. 1-2 Combined Issue. Retrieved from: https://www.nepjol.info/index.php/EJDI/issue/view/1217.

Federal Reserve Economic Data | FRED | St. Louis Fed. (2020). ROE. Retrieved from: https://fred.stlouisfed.org/.

Karim, M. Z. K.., Chan, S., \& Hassan, S. (2010). Bank Efficiency and Non-Performing Loans: Evidence from Malaysia and Singapore, Prague Economic Papers, 2, 118-132. DOI: 10.18267/j.pep.367

International Monetary found. (2018), “Index". Retrieved from: https://www.imf.org/external/index.htm.

National Bank of the Republic of Macedonia. (May 2017). Research activity program in the period $2018-2020$. Skopje. Retrieved from: http://www.nbrm.mk/banking_system_reports.nspx.

The World Bank. IBRD-IDA. (2019). Non-performing loans. Retrieved from: http://www.worldbank.org/;

The World Bank. IBRD-IDA. (2019). GDP growth. Retrieved from: http://www.worldbank.org/.

Joseph, M.T., Gwangwava, E., Faitira, M., Mutibvu, C. and Kamoyo, M. (2012): Nonperforming loans in commercial banks A case of commercial banks in Zimbabwe; Interdisciplinary Journal of Contemporary Research in Business, Vol.4.No7. Retrieved from: https://docplayer.net/12116784Non-performing-loans-in-commercial-banks-a-case-of-cbz-bank-limited-in-zimbabwe.html

Sontakke, N. R. and Tiwari, C. (2013): Trend Analysis of Nonperforming Asset in Scheduled Commercial Banks in India; International Journal of Application or Innovation in Engineering \&Management (IJAIEM); ISSN 2319 - 4847. Retrieved from: https://www.ijaiem.org/RATMIG2013/MGT\%2010\%20Trend_Analysis_of_NPA_in_Scheduled_Commercial_Banks_in_India.pdf 